\title{
Ethyl 4,4-dimethyl pyroglutamate (DMPG): a chiral auxiliary in cyclopropanation and carbonyl group activator
}

 \\ Juan F. Espinosa, ${ }^{b}$ Alfonso Rivera-Sagredo, ${ }^{b}$ and Jesús Ezquerra*b \\ ${ }^{a}$ Departamento. de Química Orgánica, Universidad de Alcalá, Campus Universitario, 28871- \\ Alcalá de Henares, Madrid, Spain \\ ${ }^{b}$ Centro de Investigación Lilly, Avda. de la Industria, 30, 28108-Alcobendas, Madrid, Spain \\ E-mail: jezquerra@lilly.com
}

This manuscript is dedicated to Prof. Julio Alvarez-Builla on occasion of his 65th birthday

\begin{abstract}
Reaction of ethyl (S)- $N$-trans-2-butenoyl-4,4-dimethyl pyroglutamate with ethyl (dimethylsulfuranylidene) acetate (EDSA) or with Trost's ylide gave rise to stereoselective cyclopropanation, promoted by the chiral auxiliary (S)-ethyl 4,4-dimethyl pyroglutamate (DMPG), which can easily be removed from the highly functionalised cyclopropanated products using various nucleophiles.
\end{abstract}

Keywords: (S)-Ethyl 4,4-dimethyl pyroglutamate (DMPG), nucleophilic stereoselective cyclopropanation

\section{Introduction}

The cyclopropane ring is found in natural products such as terpenes, pheromones and some amino acids. ${ }^{1}$ General methods for the cyclopropanation of olefins include the Simmons-Smith reaction $^{2}$ and reaction with diazomethane/palladium acetate ${ }^{3}$ and diazoesters. ${ }^{4}$ Corey also demonstrated that the addition of dimethyl sulfoxonim methylide to $\alpha, \beta$-unsaturated ketones affords the corresponding cyclopropyl ketones. ${ }^{5}$ This method, which involves sequential Michael addition followed by intramolecular displacement of dimethyl sulfoxide, has become widely appreciated as the most general procedure for cyclopropanation of activated, electron deficient alkenes (Scheme 1). Furthermore, other sulfur ${ }^{6}$ or phosphorus ylides ${ }^{7}$ have been successfully employed in cyclopropanations using various types of Michael acceptor. 

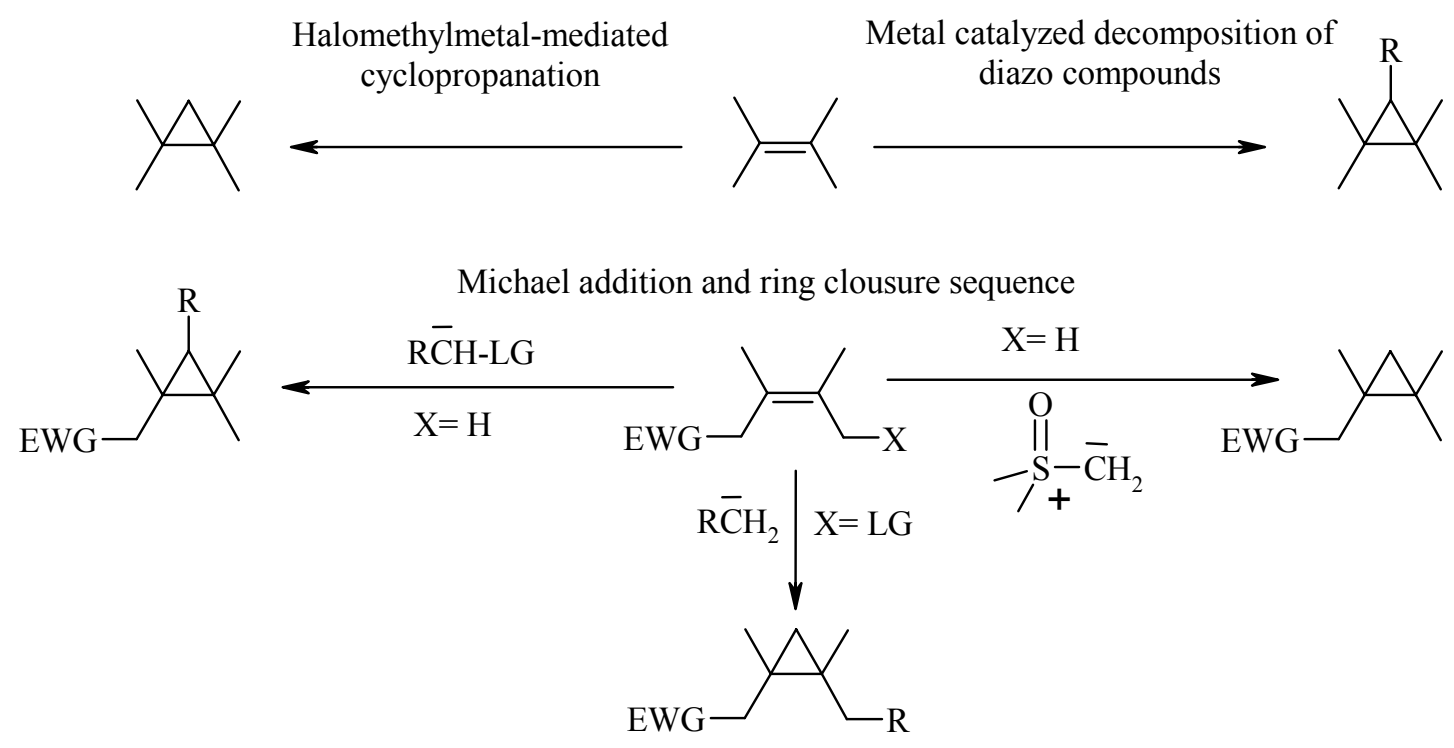

\section{Scheme 1}

Although there are a variety of stereoselective methods for the cyclopropanation of electron-rich olefins, ${ }^{8}$ the number of reports focused on the stereoselective cyclopropanation of enones and related $\alpha, \beta$-unsaturated compounds is quite limited. Previous examples included stereoselective cyclopropanation of cyclic enones ${ }^{9}$ and optically active acyclic enolates or enones derived from glyceraldehyde acetonide (Garner's adehyde). ${ }^{10}$ Hanessian et al have reported an efficient asymmetric cyclopropanation using chloroallyl phosphonamides. ${ }^{11}$ More recently an enantioselective cyclopropanation of $\mathrm{N}$-enoyloxazolidinones ${ }^{12}$ mediated by Lewis acids has been reported and Barluenga ${ }^{13}$ has described the diastereo- and enantioselective cyclopropanantion of alkenyl oxazolines with chromium Fischer carbene complexes. Our contributions in the field include the diastereoselective cyclopropanation of cyclic and acyclic enones with ethyl dimethylsulfonium acetate bromide, ${ }^{14}$ and the stereoselective cyclopropanation of enantiomerically pure dihydroxycyclopentenones for the enantioselective synthesis of 2aminobicyclo[3.1.0]hexane-2,6-dicarboxylic acid. ${ }^{15}$ In the light of our findings with (S)-ethyl 4,4-dimethyl pyroglutamate 1 (DMPG) ${ }^{16}$ as an efficient chiral auxiliary in stereoselective aldol condensations $^{17}$ and asymmetric Michael addition ${ }^{18}$ reactions, it was of interest to explore the behaviour of $N$-enoyl substrates incorporating DMPG towards an stereoselective cyclopropanation reaction. The DMPG group will not only activate the $N$-enoyl carbonyl group for the cyclopropanation reaction but also it will provide a means for further functionalization when reacted with an appropriate nucleophile. This synthetic approach will deliver cyclopropyl containing compounds $\mathbf{5}$ in an enantiomerically pure form as compared with our racemic cyclopropanation of acyclic $\alpha, \beta$-unsaturated ketones. ${ }^{14}$ Additionally since the removal of the quiral auxiliary requires the reaction of 2 with a nucleophile, this single synthetic approach can deliver cyclopropanated products as those arising from esters, amides or ketones 5a-d from a 
single substrate. (Scheme 2)

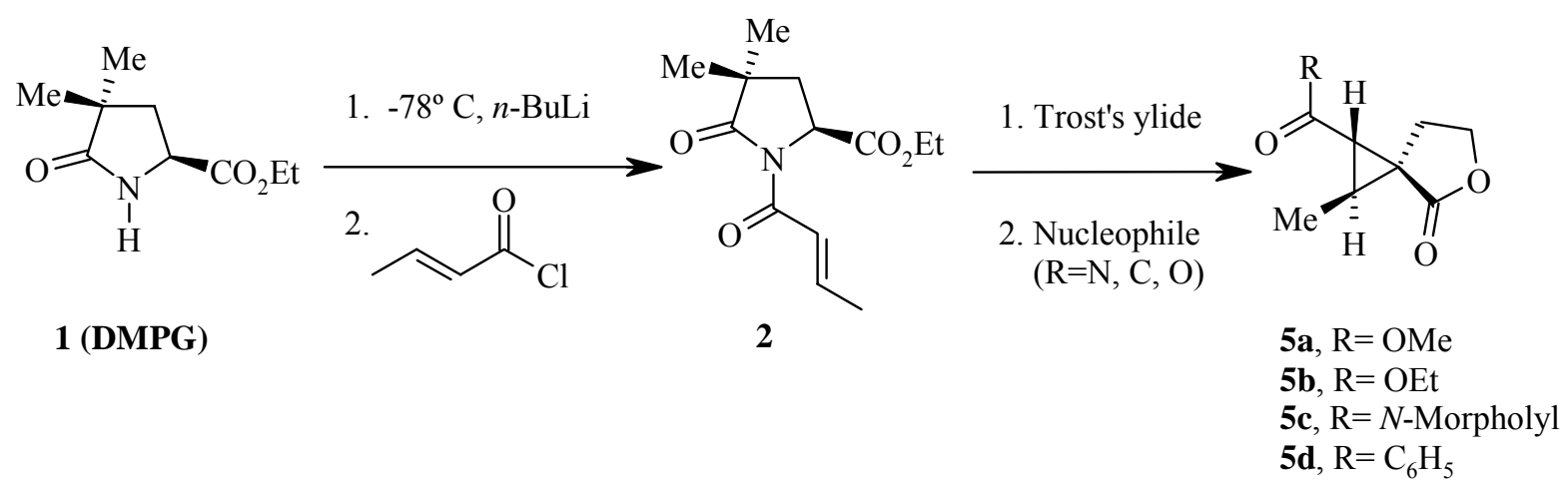

\section{Scheme 2}

\section{Results and Discussion}

In this communication, we report our results concerning the successful reaction of ethyl (S)- $N$ trans-2-butenoyl-4,4-dimethyl pyroglutamate 2 with sulfonium ylides, leading to cyclopropanes with a high degree of diastereoselectivity, and the subsequent chemoselective removal of the auxiliary, using both heteronucleophiles and C-nucleophiles. The pyroglutamate derivative 2 used in this study was obtained in an $80 \%$ yield by treatment of 1 with $n$-butyllithium followed by reaction with crotonyl chloride. ${ }^{16,18}$ The dimethylsulfonium acetate bromide (EDSA) ${ }^{19}$ and S,S-dimethyl-S-(2-oxotetrahydro-3-furyl)sulfonium fluoroborate ${ }^{20}$ (Trost's salt) used in this study were prepared following literature procedures.

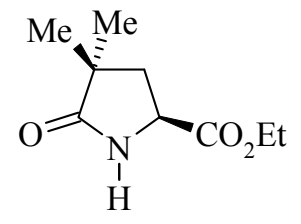

1 (DMPG)

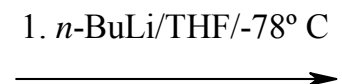

2 .



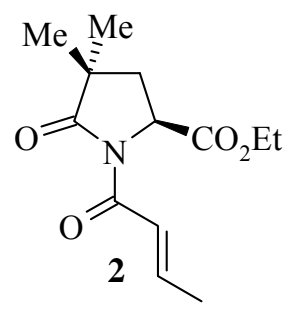

\section{Scheme 3}

Based on our previous studies with enones and ethyl dimethylsulfonium acetate bromide, ${ }^{14,15}$ 1,8-diazabicyclo-[5,4,0] undec-7-ene (DBU) was chosen as base to generate in situ ethyl (dimethylsulfuranylidene) acetate (EDSA) from the sulfonium salt. In toluene at room temperature 2 reacted slowly with EDSA giving, after 90 h, a mixture of cyclopropanes $3 \mathbf{a}^{-\mathbf{d}^{21}}$ in a $63 \%$ yield. The yield of the cyclopropanation was improved to $87 \%$ by use of a $1: 1$ mixture of $\mathrm{THF} / \mathrm{CH}_{3} \mathrm{CN}$, in only $36 \mathrm{~h}$ at room temperature (Scheme 4). 


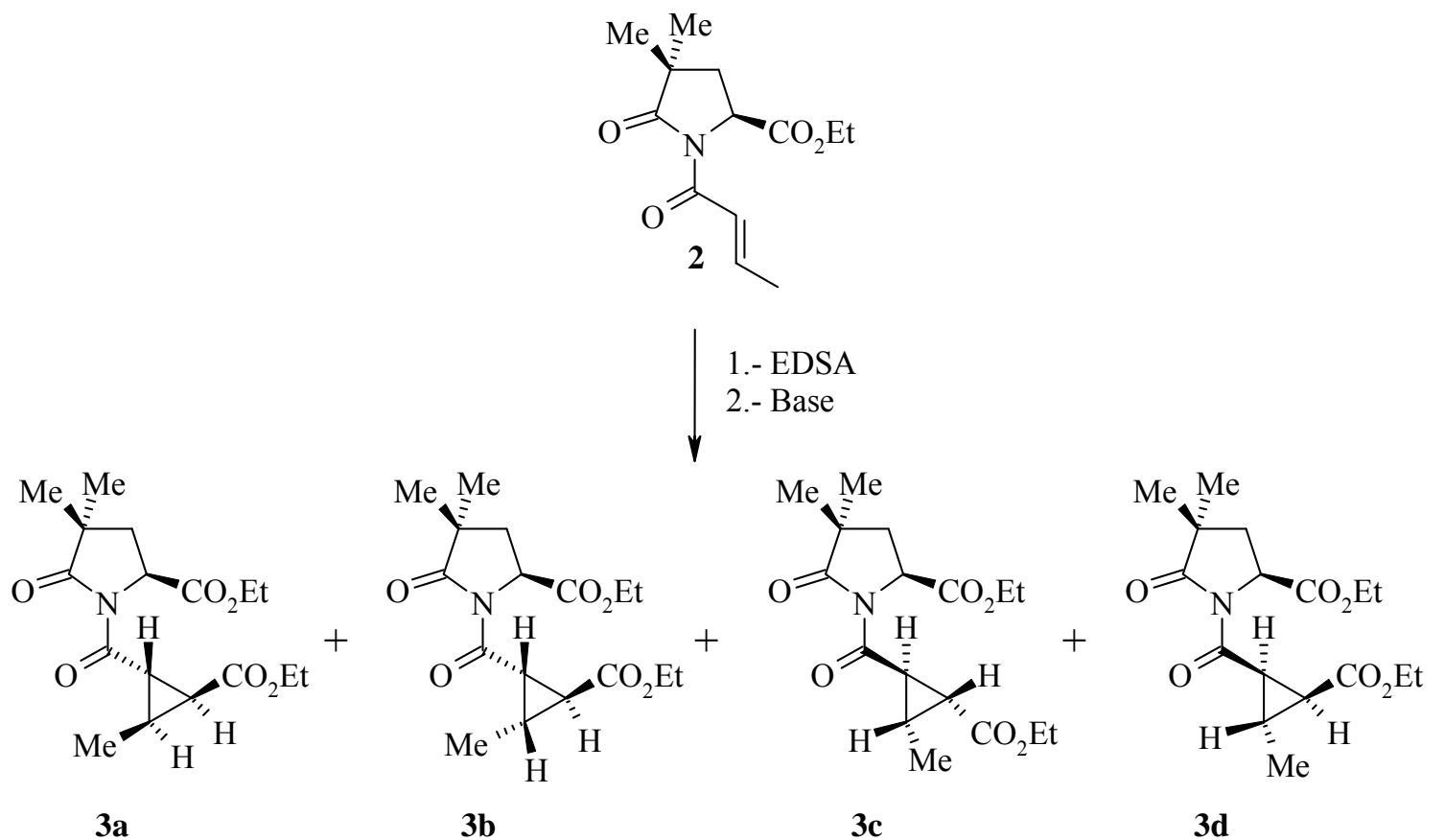

\section{Scheme 4}

Table 1 shows the stereoselectivity of the cyclopropanation under the above conditions. Changes in solvent, temperature and reaction time did not improve the sterereoselectivity of the reaction.

Table 1. Cyclopropanation with EDSA

\begin{tabular}{cccccc}
\hline Entry & Solvent & Conditions & \multicolumn{3}{c}{ Yield (Prod. ratio $\left.{ }^{\mathrm{a}}\right)$} \\
\hline & & & $3 a+3 b$ & $3 \mathbf{3 c}$ & 3d \\
$1^{\mathrm{b}}$ & Toluene & $\mathrm{rt}, 90 \mathrm{~h}$ & $18 \%(11)$ & $45 \%(27)$ & $2 \%(1)$ \\
2 & Toluene & $40{ }^{\circ} \mathrm{C}, 24 \mathrm{~h}$ & \multicolumn{3}{c}{ Decomposition } \\
$3^{\mathrm{b}}$ & MeCN/THF $(1: 1)$ & $\mathrm{rt}, 36 \mathrm{~h}$ & $42 \%(2)$ & $21 \%(1)$ & $20 \%(1)$ \\
4 & MeCN/THF $(1: 2)$ & $5{ }^{\circ} \mathrm{C}, 24 \mathrm{~h}$ & \multicolumn{3}{c}{ Low conversion } \\
5 & MeCN/THF $(1: 2)$ & $\mathrm{rt}, 24 \mathrm{~h}$ & $25 \%(2)$ & $25 \%(2)$ & $11 \%(1)$ \\
6 & Toluene/MeCN $(8: 1)$ & $\mathrm{rt}, 24 \mathrm{~h}$ & $25 \%(5)$ & $24 \%(5)$ & $5 \%(1)$ \\
7 & Toluene/MeCN $(1: 1)$ & $\mathrm{rt}, 24 \mathrm{~h}$ & $18 \%(1)$ & $20 \%(1)$ & $18 \%(1)$ \\
8 & Toluene/THF $(8: 1)$ & $\mathrm{rt}, 24 \mathrm{~h}$ & $22 \%(1)$ & $20 \%(1)$ & $22 \%(1)$ \\
9 & Toluene/THF/MeCN $(2: 1: 1)$ & $\mathrm{rt}, 24 \mathrm{~h}$ & $15 \%(2)$ & $15 \%(2)$ & $6 \%(1)$ \\
\hline
\end{tabular}

${ }^{a}$ Data obtained by NP-HPLC. ${ }^{b}$ Entry 1: ratio 3a/3b (6:1); Entry 3: ratio 3a/3b (3:2) (ratio obtained by chiral NP-HPLC).

Reaction of 2 with the ylide generated from Trost's salt $\left(\mathrm{HNa} / \mathrm{THF} / \mathrm{CH}_{3} \mathrm{CN}\right)$ afforded the expected cyclopropanes in yields ranging from $72 \%$ to $91 \%$, depending upon the excess of the 
salt used, the yield being optimal when the reaction was carried out with 1.5 equiv. Analysis of the reaction product showed that it was a mixture of four components. The two major cyclopropanes $\mathbf{4 a}$ and $\mathbf{4 b}$ represent an $80 \%$ yield and could be separated by chromatography (4:1 ratio) while the mixture $\mathbf{4 c / 4 d}(11 \%)$ was analyzed by NMR; the ${ }^{1} \mathrm{H}$ spectrum reveals a 4:1 ratio of products in the mixture (Scheme 5).

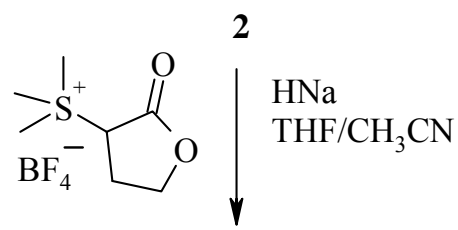



4a

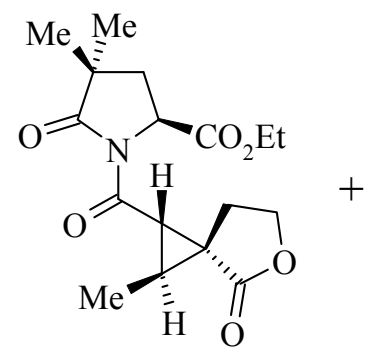

4b<smiles>CCOC(=O)C1CC(C)(C)C(=O)N1C(=O)C1[C@H](C)[C@]12CCOC2=O</smiles>

4c<smiles>CCOC(=O)C1CC(C)(C)C(=O)N1C(=O)[C@H]1[C@H](C)[C@]12CCOC2=O</smiles>

4d

4a-d ratio: $32: 8: 4: 1$

\section{Scheme 5}

The stereochemistry of cyclopropanes $\mathbf{3}$ and $\mathbf{4}$ was determined by NMR spectroscopy. The initial step was the assignment of resonances through a combination of ${ }^{1} \mathrm{H}$, gCOSY and gHSQC experiments. The relative configuration of isomers 3 was deduced from ${ }^{3} \mathrm{JHH}$ analysis. For instance, the relevant coupling constants for $3 \mathrm{a}$ are ${ }^{3} \mathrm{~J}_{7-8}=4.7 \mathrm{~Hz},{ }^{3} \mathrm{~J}_{7-9}=5.0 \mathrm{~Hz}$ and ${ }^{3} \mathrm{~J}_{8-9}=9.5$ $\mathrm{Hz}$. Since it is well established that for cyclopropanes ${ }^{3} \mathrm{Jcis}>^{3} \mathrm{Jtrans}$, these values indicate that $\mathrm{H} 7$ is trans to both $\mathrm{H} 8$ and H9. This assignment was confirmed through NOE data, as shown in Figure 1.

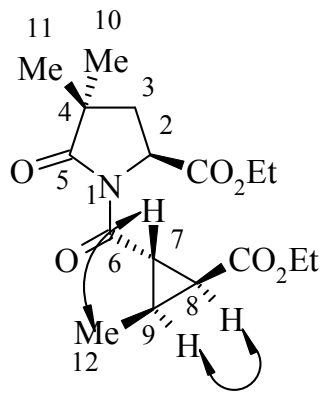

3a

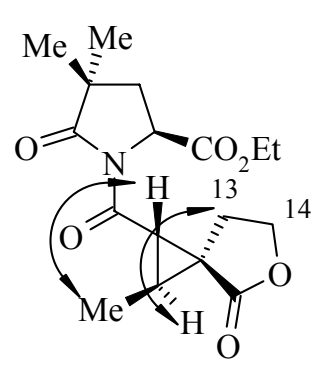

4a

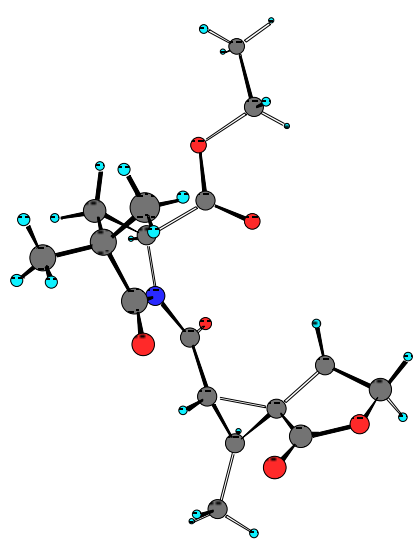

Figure 1. Representative NOEs for major isomers 3a and 4a (left) and X-ray structure of 4a (right). 
Similar analyses were carried out for compounds $\mathbf{3 b}$ and $\mathbf{3 c}$. Furthermore, the relative configuration of cyclopropanes $\mathbf{4 a}$ and $\mathbf{4 b}$ was elucidated through $1 \mathrm{D}$ and 2D-NOESY experiments. Strong NOEs between $\mathrm{H} 7$ and the methyl protons were observed for both isomers. On the other hand, the methylene protons of the lactone ring showed a NOE to H9 for $\mathbf{4 a}$ and to the methyl protons for $\mathbf{4 b}$. The observed NOEs reveal that H7 is cis to the methyl group in both isomers and the difference between them lies in the configuration at C8 (Figure 1). Chemical shifts, $\mathbf{J}_{7-9}$ value and NOE effects for $\mathbf{4} \mathbf{c}$ are very similar to those found for $\mathbf{4 a}$, reflecting that both isomers have the same relative configuration in the cyclopropane ring. Similarly, $\mathbf{4 b}$ and $\mathbf{4 d}$ also present the same configuration in the ring. The absolute configuration of these derivatives was established by X-ray analysis of $4 \mathbf{a}^{22}$ (Figure 1) confirming the anticipated result from the NMR structural analysis.

These results contrast with our previous studies where EDSA reacted with enones but showed a lack of reactivity towards $\alpha, \beta$-unsaturated aldehydes, esters, nitriles and amides. ${ }^{14}$ Furthermore, although the stereoselectivity in the reaction with EDSA is low, DMPG promotes cyclopropanation in excellent yields and with a good level of diastereoselection under nonchelation control conditions of the substrate ${ }^{9,12}$ when Trost's salt is used as the sulfonium ylide precursor. The origin of this diastereoselectivity presumably involves a dominant reactive rotamer for 2 with predominant attack of the ylide at the $\beta$-carbon from the opposite face to the pyroglutamate carboxylate group. This simple model, however, does not entirely unravel the selectivity observed with the Trost's salt when compared with EDSA. The question remains whether ylides themselves or the different bases used in the two reactions (DBU and $\mathrm{HNa}$ ) are responsible for the different diastereoselectivity observed. Unfortunately, our attempts to study the role of the base on the stereoselectivity failed due to the lack of reactivity of Trost's salt in the presence of DBU and the poor yield of cyclopropanated products obtained when $\mathrm{HNa}$ was used to generate the EDSA ylide. We have recently shown that DMPG can be selectively removed by chemoselective nucleophilic displacement on $\mathrm{N}$-acyl DMPG derivatives, with O-, $\mathrm{N}$-, and C-nucleophiles. ${ }^{23}$

The removal of the DMPG from the cyclopropane 4a presents an extra challenge, in terms of nucleophile selectivity, with the introduction of the lactone carbonyl. We have found that the DMPG could be chemoselectively removed from 4a using alkoxides, amines or Grignard reagents, giving the corresponding tetrasubstituted cyclopropanes 5a-d in good yields and without erosion of their stereochemical integrity (Scheme 6). In summary, we have shown that the cyclopropanation reaction of (S)-N-trans-2-butenoyl-4,4-dimethyl pyroglutamate with sulfonium ylides proceeds in high yields and with diastereocontrol of the stereogenic centers of the cyclopropane ring. Moreover, the chiral auxiliar (DMPG) can be chemoselectively removed from the cyclopropanated compounds using heteronucleophiles and Grignard reagents, permitting recovery of DMPG and formation of highly functionalised cyclopropanes. 
<smiles>[R]OC(=O)[C@]1(C(C)C)[C@H](C)[C@]12CCOC2=O</smiles>

5a, $\mathrm{R}=\mathrm{OEt}(78 \%)$

$5 \mathbf{b}, \mathrm{R}=\mathrm{OMe}(85 \%)$


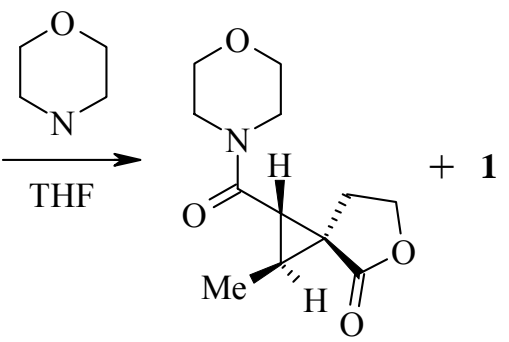

$5 c(67 \%)$

\section{Scheme 6}

\section{Experimental Section}

General. All common reagents and solvents were obtained from commercial suppliers and used without any further purification unless otherwise indicated. NP-HPLC analytical work was recorded at Series 1100 Liquid Chromatography / Mass Selective Detector LC/MSD (Agilent, Waldbronn, Germany) driven by ChemStation software. NP-HPLC semi-preparative work was recorded at Waters Delta Prep 4000 Liquid Chromatography / Photodiode Array Detector (Waters, USA) controlled through Mass Lynx software. NP-HPLC preparative work was recorded at Hipersep Lab LC 50-80 system/variable ultraviolet and Refractive Index Detectors (Novasep, France) driven by ChromSoftLab central system (iFIXTM software). Enantiomeric excess values were determined by HPLC on a Chiralcel OD-H as chiral column. NMR spectra were recorder in a Bruker DRX-500 and Bruker DPX-300 spectrometers. ${ }^{1} \mathrm{H}$ NMR experiments were recorded in $\mathrm{CDCl}_{3}$ at $500 \mathrm{MHz}$ or $300 \mathrm{MHz}$ at $20^{\circ} \mathrm{C}$ with tetramethylsilane as internal standard. ${ }^{13} \mathrm{C}$ NMR spectra were recorded in $\mathrm{CDCl}_{3}$ at $125 \mathrm{MHz}$ or $75 \mathrm{MHz}$ and at $20^{\circ} \mathrm{C}$. Optical rotations were obtained on Perkin Elmer 343, values were determined using the sodium lamp and the concentration was reported on $g / 100 \mathrm{~mL}$. Microanalysis for all new compounds was performed in the analytical laboratory of the Alcalá de Henares University.

Ethyl (S)- $N$-(trans-2-butenoyl)-4,4-dimethyl pyroglutamate (2). Over a THF solution (5 mL) of 1 (430 mg, $2.32 \mathrm{mmol}$ ) cooled to $-78^{\circ} \mathrm{C}$ under argon atmosphere was added a solution of $n$ Buli $1.6 \mathrm{M}$ in hexanes $(1.44 \mathrm{~mL}, 2.55 \mathrm{mmol})$ keeping on the temperature below $-74{ }^{\circ} \mathrm{C}$. The mixture was stirred for 5 minutes at $-78{ }^{\circ} \mathrm{C}$ and a solution of trans-crotonylchloride $(90 \%$ tech. 
Grade) $(0.4 \mathrm{~mL}, 4.17 \mathrm{mmol})$ in THF $(2.5 \mathrm{~mL})$ was added in $0.5 \mathrm{~h}$, keeping on the temperature below $-74{ }^{\circ} \mathrm{C}$. The reaction mixture was quenched with $\mathrm{NH}_{4} \mathrm{Cl}(5 \mathrm{~mL})$ at $-78{ }^{\circ} \mathrm{C}$ and allowed to warm to room temperature. The organic phase was separated and the aqueous phase washed with $\mathrm{Et}_{2} \mathrm{O}(2 \times 5 \mathrm{~mL})$. The combined organic layers were dried over $\mathrm{MgSO}_{4}$, filtered and the solvent evaporated under reduced pressure. The residue was purified by chromatography NP-HPLC Kromasil $60(10 \mu \mathrm{m}, 8 \times 18 \mathrm{~cm})]$ using hexane/acetone $85: 15$ to give $450 \mathrm{mg}(76 \%)$ of 2 . A second purification by chiral NP-HPLC [Chiralcel OD $(10 \mu \mathrm{m}, 2 \times 25 \mathrm{~cm}) 12 \mathrm{ml} / \mathrm{min}$ ] gives 311 $\operatorname{mg}($ ee $>98 \%)$.

$[\alpha]_{\mathrm{D}}{ }^{21}=-32.6^{\mathrm{o}}\left(\mathrm{c} 0.40, \mathrm{CH}_{2} \mathrm{Cl}_{2}\right)$; Lit. ${ }^{16,17}[\alpha]_{\mathrm{D}}{ }^{21}=-34.5^{\circ}\left(\mathrm{c} 0.31, \mathrm{CH}_{2} \mathrm{Cl}_{2}\right) .{ }^{1} \mathrm{H}$ NMR $(300 \mathrm{MHz}$, $\left.\mathrm{CDCl}_{3}\right) \delta(\mathrm{ppm}): 7.28(\mathrm{~d}, 1 \mathrm{H}, J=15.4 \mathrm{~Hz}, \mathrm{H} 7) ; 7.06-7.28(\mathrm{~m}, 1 \mathrm{H}, \mathrm{H} 8) ; 4.65(\mathrm{dd}, 1 \mathrm{H}, J=5.0,9.2$ $\mathrm{Hz}, \mathrm{H} 2$ ); 4.21 (q, $2 \mathrm{H}, J=7.2 \mathrm{~Hz}, \mathrm{OCH}_{2} \mathrm{CH}_{3}$ ); 2.23 (dd, $\left.1 \mathrm{H}, J=9.6,13.4 \mathrm{~Hz}, \mathrm{H} 3 \mathrm{a}\right) ; 1.87-1.97$ (m, 4H, Me-9, H3b); 1.27 (t, 3H, $J=7.2 \mathrm{~Hz}, \mathrm{OCH}_{2} \mathrm{CH}_{3}$ ); 1.24 (s, 3H, Me-10); 1.22 (s, 3H, Me-11). ${ }^{13} \mathrm{C} \mathrm{NMR}\left(75 \mathrm{MHz}, \mathrm{CDCl}_{3}\right) \delta(\mathrm{ppm}): 183.1,174.6,170.9,145.9,122.2,60.6,54.2,51.8,43.5$, $34.9,24.7,23.7,13.0$.

\section{Cyclopropanation Reactions}

Ethyl (S)-4,4-dimethyl- $N$-(2-ethoxycarbonyl-3-methylcyclo propanocarbonyl)pyroglutamate (3) Method A. A solution of $(\mathrm{EDSA})^{19}(124 \mathrm{mg}, 0.54 \mathrm{mmol})$ and DBU $(82 \mu \mathrm{l}, 0.54 \mathrm{mmol})$ in toluene was stirred at room temperature for 30 minutes under argon. Then, was added 2 (90 mg, $0.36 \mathrm{mmol})$ in toluene $(1 \mathrm{~mL})$ and the mixture was stirred at room temperature for $90 \mathrm{~h}$. The reaction mixture was quenched with a saturated solution of $\mathrm{NH}_{4} \mathrm{Cl}(5 \mathrm{~mL})$, extracted with $\mathrm{Et}_{2} \mathrm{O}$ $(3 \times 10 \mathrm{~mL})$ and the organic phase dried over $\mathrm{MgSO}_{4}$. The solvent was evaporated in vacuo and the residue purified by chromatography on silica gel with hexane/EtOAc 9:1 to give a mixture of 3a-d (63\%).

Method B. A solution of (EDSA) (500 mg, $2.2 \mathrm{mmol})$ and DBU (0.34 mL, $2.2 \mathrm{mmol})$ in $\mathrm{THF} / \mathrm{CH}_{3} \mathrm{CN}$ (2:1) was stirred at room temperature for 30 minutes under argon. Then, was 2 added $(380 \mathrm{mg}, 1.5 \mathrm{mmol})$ in toluene $(1 \mathrm{~mL})$ and the mixture was stirred at room temperature for $36 \mathrm{~h}$. The reaction mixture was quenched with a saturated solution of $\mathrm{NH}_{4} \mathrm{Cl}(5 \mathrm{~mL})$, extracted with $\mathrm{Et}_{2} \mathrm{O}(3 \times 10 \mathrm{~mL})$ and the organic phase dried over $\mathrm{MgSO}_{4}$. The solvent was evaporated under reduced pressure and the residue purified by chromatography with hexane/EtOAc (9:1) to give a mixture of 3a-d (87\%). Cyclopropanes 3a-d were separated by semiprep-HPLC.

Ethyl (2S)-1-[(1S,2S,3S)-2-ethoxycarbonyl-3-methyl-cyclopropanecarbonyl]-4,4-dimethyl5-oxo-pyrrolidine-2-carboxylate (3a). ${ }^{1} \mathrm{H}$ NMR (500 MHz, $\mathrm{CDCl}_{3}$ ) $\delta$ (ppm) $1.25-1.30$ (m, 12 $\left.\mathrm{H}, \mathrm{Me}-10, \mathrm{Me}-11,2 \mathrm{CH}_{2} \underline{\mathrm{H}}_{3}\right) 1.34$ (d, $\left.J=6.4 \mathrm{~Hz}, 3 \mathrm{H}, \mathrm{Me}-12\right) 1.88$ - 1.97 (m, $2 \mathrm{H}, \mathrm{H} 9$ and H3a) 2.24 (dd, $J=13.3,9.6 \mathrm{~Hz}, 1 \mathrm{H}, \mathrm{H} 3 \mathrm{~b}) 2.42$ (dd, $J=9.6,4.7 \mathrm{~Hz}, 1 \mathrm{H}, \mathrm{H} 8) 3.67$ (t, $J=5.2 \mathrm{~Hz}, 1 \mathrm{H}$, H7) 4.14 - $4.25\left(\mathrm{~m}, 4 \mathrm{H}, 2 \mathrm{CH}_{2} \mathrm{CH}_{3}\right) 4.59$ (dd, $\left.J=9.5,4.9 \mathrm{~Hz}, 1 \mathrm{H}, \mathrm{H} 2\right) .{ }^{13} \mathrm{C} \mathrm{NMR}(125 \mathrm{MHz}$, $\left.\mathrm{CDCl}_{3}\right) \delta(\mathrm{ppm}): 179.5,171.1,170.0,169.3,61.3,60.7,55.1,42.5,35.9,29.1,29.0,25.7,25.6$, 25.1, 14.0, 11.3. Anal. calcd for $\mathrm{C}_{17} \mathrm{H}_{25} \mathrm{NO}_{6}$ : C, 60.16; H, 7.42; N, 4.13. Found: C, 60.22; H, $7.17 ; \mathrm{N}, 3.96$. 
Ethyl (2S)-1-[(1S,2S,3R)-2-ethoxycarbonyl-3-methyl-cyclopropanecarbonyl]-4,4-dimethyl5-oxo-pyrrolidine-2-carboxylate (3b). ${ }^{1} \mathrm{H}$ NMR $\left(500 \mathrm{MHz}, \mathrm{CDCl}_{3}\right) \delta$ (ppm) 1.19 (d, $J=6.4$ $\mathrm{Hz}, 3 \mathrm{H}, \mathrm{Me}-12) 1.25$ - 1.30 (m, $\left.12 \mathrm{H}, \mathrm{Me}-10, \mathrm{Me}-11,2 \mathrm{CH}_{2} \mathrm{CH}_{3}\right) 1.96$ (dd, $J=13.4,4.6 \mathrm{~Hz}, 1$ H, H3a) $2.04-2.12$ (m, $1 \mathrm{H}, \mathrm{H} 9) 2.25$ (dd, $J=13.4,9.8 \mathrm{~Hz}, 1 \mathrm{H}, \mathrm{H} 3 \mathrm{~b}) 2.31$ (t, $J=5.2 \mathrm{~Hz}, 1 \mathrm{H}$, H8) 3.69 (dd, $J=10.1,4.9 \mathrm{~Hz}, 1 \mathrm{H}, \mathrm{H} 7) 4.11-4.24\left(\mathrm{~m}, 4 \mathrm{H}, 2 \mathrm{C}_{2} \mathrm{CH}_{3}\right) 4.63$ (dd, $J=9.6,4.7$ $\mathrm{Hz}, 1 \mathrm{H}, \mathrm{H} 2) .{ }^{13} \mathrm{C} \mathrm{NMR}\left(125 \mathrm{MHz}, \mathrm{CDCl}_{3}\right) \delta$ (ppm): 179.4, 171.2, 170.0, 169.5, 61.2, 60.7, 55.2, 42.6, 35.8, 29.0, 27.8, 25.8, 25.3, 25.1, 14.0, 10.9. Anal. calcd for $\mathrm{C}_{17} \mathrm{H}_{25} \mathrm{NO}_{6}$ : C, 60.16; H, 7.42; N, 4.13. Found: C, 60.21; H, 7.17; N, 3.97.

Ethyl (2S)-1-[(1R,2R,3R)-2-ethoxycarbonyl-3-methyl-cyclopropanecarbonyl]-4,4-dimethyl5-oxo-pyrrolidine-2-carboxylate (3c). ${ }^{1} \mathrm{H}$ NMR (500 MHz, $\left.\mathrm{CDCl}_{3}\right) \delta(\mathrm{ppm}) 1.24-1.35$ (m, 15 $\mathrm{H}, \mathrm{Me}-10$, Me-11, Me-12, $2 \mathrm{CH}_{2} \underline{\mathrm{C}}_{3}$ ) 1.83-1.91 (m, $\left.1 \mathrm{H}, \mathrm{H} 9\right) 1.95$ (dd, $J=13.3,5.3 \mathrm{~Hz}, 1 \mathrm{H}$, H3a) 2.24 (dd, $J=13.1,9.5 \mathrm{~Hz}, 1 \mathrm{H}, \mathrm{H} 3 \mathrm{~b}) 2.45$ (dd, $J=9.5,4.6 \mathrm{~Hz}, 1 \mathrm{H}, \mathrm{H} 8) 3.66$ (t, $J=5.2 \mathrm{~Hz}$, $1 \mathrm{H}, \mathrm{H} 7) 4.15-4.25$ (m, $\left.4 \mathrm{H}, 2 \mathrm{CH}_{2} \mathrm{CH}_{3}\right) 4.60$ (dd, $\left.J=9.5,5.2 \mathrm{~Hz}, 1 \mathrm{H}, \mathrm{H} 2\right) .{ }^{13} \mathrm{C}$ NMR (125 $\left.\mathrm{MHz} \mathrm{CDCl}_{3}\right) \delta(\mathrm{ppm}): 179.2,170.9,170.8,169.6,61.3,60.6,55.1,42.4,35.9,29.1,29.0,25.6$, 25.5, 25.0, 13.9, 11.2. Anal. calcd for $\mathrm{C}_{17} \mathrm{H}_{25} \mathrm{NO}_{6}$ : C, 60.16; H, 7.42; N, 4.13. Found: C, 60.22; H, 7.17; N, 3.96.

Ethyl (2S)-4,4-dimethyl- $\mathrm{N}$-(2-methyl-4-oxo-5-oxaspiro[2.4]heptan-1-carbonyl) pyroglutamate (4). To a solution of the Trost's salt ${ }^{20}$ (695 mg, $\left.2.97 \mathrm{mmol}\right)$ in THF/CH $\mathrm{CH}_{3} \mathrm{CN}$ (2:1), NaH (72 mg, 2.97 mmol) was slowly added at room temperature under argon. When evolution of hydrogen was finished, 2 (500 mg, $1.98 \mathrm{mmol})$ in THF $(5 \mathrm{~mL})$ was added and the mixture was heated at reflux temperature for $12 \mathrm{~h}$. Then the reaction mixture was quenched with a saturated solution of $\mathrm{NH}_{4} \mathrm{Cl}(10 \mathrm{~mL})$, extracted with $\mathrm{CH}_{2} \mathrm{Cl}_{2}(3 \times 15 \mathrm{~mL})$ and the organic phase dried over $\mathrm{MgSO}_{4}$. The solvent was evaporated under reduced pressure and the residue chromatographed on silica gel. Elution with hexane/EtOAc (7:3) allowed to separate compounds 4a and 4b (80\% yield, 4:1 ratio) and a mixture of $\mathbf{4 c / 4 d}$ (11\% yield, $4: 1$ ratio by ${ }^{1} \mathrm{H}$ NMR).

Ethyl (2S)-N-[(1S,2S,3R)-(2-methyl-4-oxo-5-oxaspiro[2.4]heptan-1-carbonyl)]-4,4-dimethylpyroglutamate (4a). White solid. Mp: $86-87^{\circ} \mathrm{C} .[\alpha]_{\mathrm{D}}{ }^{21}=-35.8^{\circ}\left(\mathrm{c} 1.25, \mathrm{CDCl}_{3}\right) .{ }^{1} \mathrm{H}$ NMR $\left(500 \mathrm{MHz}, \mathrm{CDCl}_{3}\right) \delta$ (ppm): 1.21 - 1.29 (m, $\left.9 \mathrm{H}, \mathrm{Me}-10, \mathrm{Me}-11, \mathrm{CH}_{2} \underline{\mathrm{C}}_{3}\right) 1.35$ (d, $J=6.3 \mathrm{~Hz}, 3 \mathrm{H}, \mathrm{Me}-12$ ) 1.93 (dd, $J=13.2,4.7$ Hz, 1 H, H3a) $2.02-2.09$ (m, 1 H, H9) 2.21 - 2.26 (m, 2 H, H3b, H13a) 2.35 -2.42 (m, $1 \mathrm{H}, \mathrm{H} 13 \mathrm{~b}) 3.62$ (d, J=6.6 Hz, $1 \mathrm{H}, \mathrm{H} 7) 4.19$ (q, $\left.J=7.1 \mathrm{~Hz}, 2 \mathrm{H}, \mathrm{C}_{2} \mathrm{CH}_{3}\right) 4.31-4.39$ (m, 2 $\left.\mathrm{H}, \mathrm{CH}_{2}-14\right) 4.61(\mathrm{dd}, J=9.6,4.6 \mathrm{~Hz}, 1 \mathrm{H}, \mathrm{H} 2) .{ }^{13} \mathrm{C} \mathrm{NMR}\left(125 \mathrm{MHz}, \mathrm{CDCl}_{3}\right) \delta(\mathrm{ppm}): 179.3$, $175.2,170.5,66.2,61.6,55.0,35.9,34.8,34.2,28.7,27.8,26.1,25.8,25.1,14.0,11.0 . \mathrm{IR}(\mathrm{KBr})$ 3460, 2983, 2360, 1772, 1747, 1682, 1456, 1374, 1286, 1200, $1019 \mathrm{~cm}^{-1}$. MS (Electrospray): $360.0\left(\mathrm{M}^{+}+\mathrm{Na}^{+}\right), 338.1\left(\mathrm{M}^{+}+1\right)$. Anal. calcd for $\mathrm{C}_{17} \mathrm{H}_{23} \mathrm{NO}_{6}: \mathrm{C}, 60.52 ; \mathrm{H}, 6.87 ; \mathrm{N}, 4.15$. Found: C, 60.24; H, 6.92; N, 3.85 .

Ethyl (2S)- $N-[(1 R, 2 R, 3 R)$-(2-methyl-4-oxo-5-oxaspiro[2.4]heptan-1-carbonyl)]-4,4-dimethylpyroglutamate (4b). Colourless oil. $[\alpha]_{\mathrm{D}}{ }^{21}=-0.8^{\mathrm{o}}\left(\mathrm{c} 0.91, \mathrm{CDCl}_{3}\right) .{ }^{1} \mathrm{H} \mathrm{NMR}\left(500 \mathrm{MHz}, \mathrm{CDCl}_{3}\right) \delta$ (ppm): 1.20 1.27 (m, 12 H, Me-10, Me-11, Me-12, $\left.\mathrm{CH}_{2} \mathrm{CH}_{3}\right) 1.98$ (dd, $\left.J=13.4,3.6 \mathrm{~Hz}, 1 \mathrm{H}, \mathrm{H} 3 \mathrm{a}\right) 2.23$ (dd, $J$ = 13.2, 10.1 Hz, $1 \mathrm{H}, \mathrm{H} 3 \mathrm{~b}) 2.30$ - 2.39 (m, $2 \mathrm{H}, \mathrm{H} 9, \mathrm{H} 13 \mathrm{a}, \mathrm{H} 9) 2.44$ - 2.51 (m, $1 \mathrm{H}, \mathrm{H} 13 \mathrm{~b}) 2.54$ (d, $J=7.6 \mathrm{~Hz}, 1 \mathrm{H}, \mathrm{H} 7) 4.12-4.28\left(\mathrm{~m}, 2 \mathrm{H}, \mathrm{CH}_{2} \mathrm{CH}_{3}\right) 4.41-4.50$ (m, $\left.2 \mathrm{H}, \mathrm{CH}_{2}-14\right) 4.59$ (dd, $J=$ 
9.8, 3.8 Hz, $1 \mathrm{H}, \mathrm{H} 2) .{ }^{13} \mathrm{C} \mathrm{NMR}(125 \mathrm{MHz}, \mathrm{CDCl} 3) \delta(\mathrm{ppm}): 180.4,174.8,170.5,166.5,65.9$, 61.7, 55.2, 42.3, 39.9, 36.1, 32.8, 27.1, 26.1, 25.1, 22.0, 13.7, 13.2. IR (NaCl) 3531, 2974, 2935, 1768, 1739, 1698, 1455, 1375, 1335, 1275, 1210, $1131 \mathrm{~cm}^{-1}$. MS (Electrospray): $\left(\mathrm{M}^{+}+\mathrm{Na}^{+}\right)$ 360.1, $\left(\mathrm{M}^{+}+1\right)$ 338.1. Anal. calcd for $\mathrm{C}_{17} \mathrm{H}_{23} \mathrm{NO}_{6}$ : C, 60.52; H, 6.87; N, 4.15. Found: C, 59.95; $\mathrm{H}, 6.97 ; \mathrm{N}, 4.25$.

\section{Reaction of (4a) with nucleophiles}

\section{Reaction with alkoxides. General procedure}

To a solution of $4 \mathrm{a}(50 \mathrm{mg}, 0.15 \mathrm{mmol})$ in the corresponding alcohol $(2 \mathrm{~mL})$, the alkoxide $(0.15$ mmol) was added and the mixture was stirred at room temperature for 30 minutes. Then the solvent was evaporated under reduced pressure and the residue dissolved in $\mathrm{CH}_{2} \mathrm{Cl}_{2}(10 \mathrm{~mL})$. The solution was washed with a saturated solution of $\mathrm{NaCl}(3 \times 5 \mathrm{~mL})$, the organic phase dried with $\mathrm{MgSO}_{4}$, the solvent evaporated under reduced pressure and the residue purified by column chromatography using hexane/EtOAc (7:3) as eluent.

(1S, 2S, 3R)-2-Ethyl-1-methoxycarbonyl-4-oxo-5-oxaspiro[2,4]heptane (5a). Colourless oil. $80 \%$ yield. $[\alpha]_{\mathrm{D}}{ }^{21}=+71.0^{\circ}\left(\mathrm{c} 1.00, \mathrm{CDCl}_{3}\right) .{ }^{1} \mathrm{H} \mathrm{NMR}\left(300 \mathrm{MHz}, \mathrm{CDCl}_{3}\right) \delta(\mathrm{ppm}): 4.41(\mathrm{ddd}, 1 \mathrm{H}$, $J=3.3,9.0,19.8 \mathrm{~Hz}, \mathrm{H} 7 \mathrm{a}) ; 4.34(\mathrm{~m}, 1 \mathrm{H}, \mathrm{H} 7 \mathrm{~b}) ; 4.14$ (q, 2H, $\left.J=7.1 \mathrm{~Hz}, \mathrm{OCH}_{2} \mathrm{CH}_{3}\right) ; 2.46(\mathrm{~m}$, $1 \mathrm{H}, \mathrm{H6a}) ; 2.30$ (ddd, $1 \mathrm{H}, J=3.3,7.3,13.4 \mathrm{~Hz}, \mathrm{H} 6 \mathrm{~b}) ; 2.19$ (d, $\left.1 \mathrm{H}, J=6.4 \mathrm{~Hz}, \mathrm{H}_{2}\right) ; 1.88$ (q, $1 \mathrm{H}$, $J=6.4 \mathrm{~Hz}, \mathrm{H} 4) ; 1.29\left(\mathrm{~d}, 3 \mathrm{H}, J=6.4 \mathrm{~Hz}, \mathrm{CH}_{3}\right) ; 1.26\left(\mathrm{t}, 3 \mathrm{H}, J=7.1 \mathrm{~Hz}, \mathrm{OCH}_{2} \underline{\mathrm{CH}}_{3}\right) .{ }^{13} \mathrm{C} \mathrm{NMR}$ $\left(75 \mathrm{MHz}, \mathrm{CDCl}_{3}\right) \delta(\mathrm{ppm}): 175.3,170.5,66.5,61.1,33.0,32.7,29.8,28.6,14.2,11.2 . \mathrm{IR}(\mathrm{NaCl})$ $3369,2983,2933,2360,1766,1726,1455,1374,1314,1239,1188,1138,1110,1028 \mathrm{~cm}^{-1}$. MS (Electrospray): $\left(\mathrm{M}^{+}+\mathrm{Na}^{+}\right)$221.1; $\left(\mathrm{M}^{+}+1\right) 199.1$ Anal. calcd for $\mathrm{C}_{10} \mathrm{H}_{14} \mathrm{O}_{4}: \mathrm{C}, 60.59 ; \mathrm{H}, 7.12$. Found: C, 60.37; H, 6.94

(1S, 2S, 3R)-2-Methyl-1-methoxycarbonyl-4-oxo-5-oxaspiro[2,4]heptane (5b). Colourless oil. $85 \%$ yield. $[\alpha] \mathrm{D} 21=+64.0^{\circ}$ (c 0.91, $\left.\mathrm{CDCl} 3\right) .1 \mathrm{H} \mathrm{NMR}(300 \mathrm{MHz}, \mathrm{CDCl} 3) \delta(\mathrm{ppm}): 4.41$ (ddd, $1 \mathrm{H}, \mathrm{J}=18.3,9.2,3.3 \mathrm{~Hz}, \mathrm{H} 7 \mathrm{a}) ; 4.36(\mathrm{ddd}, 1 \mathrm{H}, \mathrm{J}=18.3,9.0,1.5 \mathrm{~Hz}, \mathrm{H} 7 \mathrm{~b}) ; 3.70$ (s, 3H, OCي $\underline{\mathrm{H}}_{3}$ ), $2.46(\mathrm{ddd}, 1 \mathrm{H}, \mathrm{J}=18.7,9.2,9.0 \mathrm{~Hz}, \mathrm{H6a}) ; 2.31$ (ddd, 1H, J = 13.4, 3.3, $1.5 \mathrm{~Hz}, \mathrm{H} 6 \mathrm{~b}) ; 2.20$ (d, $1 \mathrm{H}, \mathrm{J}=6.4 \mathrm{~Hz}, \mathrm{H} 2) ; 1.88(\mathrm{q}, 1 \mathrm{H}, \mathrm{J}=6.4 \mathrm{~Hz}, \mathrm{H} 4) ; 1.29$ (d, 3H, J = 6.4 Hz, CH $\mathrm{CH}_{3}$. 13C NMR (75 $\mathrm{MHz}, \mathrm{CDCl} 3) \delta(\mathrm{ppm}): 175.5,168.2,65.6,52.3,36.7,31.2,26.7,23.3,13.2$. IR (NaCl) 2962, 2935, 1766, 1732, 1445, 1375, 1339, 1240, 1198, $1028 \mathrm{~cm}-1$. MS (Electrospray): 207.0 (M++ $\mathrm{Na}+), 185.1(\mathrm{M}++1)$. Anal. calcd for C9H12O4: C, 58.69; H, 6.57. Found: C, 58.57; H, 6.46.

(1S,2S,3S)-2-Methyl-1-(morpholino-4-carbonyl)-5-oxaspiro[2,4]-4-heptanone (5c). A mixture of 4a $(0.15 \mathrm{mmol})$ and morpholine $(0.15 \mathrm{mmol})$ in THF $(3 \mathrm{~mL})$ was stirred at reflux temperature for 24 $\mathrm{h}$ under argon. Then the reaction mixture was treated with a saturated solution of $1 \mathrm{~N} \mathrm{de} \mathrm{HCl}(5$ $\mathrm{mL})$ and extracted with $\mathrm{CH}_{2} \mathrm{Cl}_{2}(3 \times 10 \mathrm{~mL})$. The organic phase was washed with a saturated solution of $\mathrm{NaCl}(2 \times 10 \mathrm{~mL})$ and dried over $\mathrm{MgSO}_{4}$. The solvent was eliminated under reduced pressure and the residue purified by column chromatography using hexane/EtOAc 6:4 as eluent. Colourless oil. $70 \%$ yield. $[\alpha]_{\mathrm{D}}{ }^{21}=+29.0^{\circ}\left(\mathrm{c} 1.15, \mathrm{CDCl}_{3}\right) .{ }^{1} \mathrm{H} \mathrm{NMR}\left(300 \mathrm{MHz}, \mathrm{CDCl}_{3}\right) \delta(\mathrm{ppm})$ : 4.30-4.50 (m, 2H, H7); 3.51 (m, 8H, $\left.\underline{\mathrm{NCH}}_{2} \underline{\mathrm{CH}}_{2} \mathrm{O}\right) ; 2.16-2.46(\mathrm{~m}, 2 \mathrm{H}, \mathrm{H} 6) ; 2.30$ (d, $1 \mathrm{H}, J=7.0$ 
$\mathrm{Hz}, \mathrm{H} 2) ; 2.08(\mathrm{q}, 1 \mathrm{H}, J=7.0 \mathrm{~Hz}, \mathrm{H} 4) ; 1.30\left(\mathrm{~d}, 3 \mathrm{H}, J=7.0 \mathrm{~Hz}, \mathrm{CH}_{3}\right) .{ }^{13} \mathrm{C} \mathrm{NMR}(75 \mathrm{MHz}$, $\left.\mathrm{CDCl}_{3}\right) \delta(\mathrm{ppm}): 176.1,163.3,66.9,66.8,66.7,46.0,42.4,32.3,31.5,28.7,28.5,11.3 . \mathrm{IR}(\mathrm{NaCl})$ 3431, 2959, 2922, 2856, 1756, 1649, 1450, 1380, 1233, 1107, $1011 \mathrm{~cm}^{-1}$. MS (Electrospray): $262.1\left(\mathrm{M}^{+}+\mathrm{Na}^{+}\right), 240.1\left(\mathrm{M}^{+}+1\right)$. Anal. calcd for $\mathrm{C}_{12} \mathrm{H}_{17} \mathrm{NO}_{4}$ : C, 60.24; H, 7.16; N, 5.85. Found: C, 60.19; H, 7.24; N, 5.76.

(1S,2S,3S)-1-Benzoyl-2-methyl-5-oxaspiro[2,4]-4-heptanone (5d). To a solution of 4a (0.15 $\mathrm{mmol})$ in THF $(3 \mathrm{~mL})$, phenylmagnesium bromide $(0.15 \mathrm{mmol})$ was added at $-40^{\circ} \mathrm{C}$ under argon and the mixture was stirred at room temperature for 4 hours. Then the reaction mixture was treated with a saturated solution of $\mathrm{NH}_{4} \mathrm{Cl}(10 \mathrm{~mL})$, allowed to warm to room temperature and extracted with $\mathrm{CH}_{2} \mathrm{Cl}_{2}(3 \times 10 \mathrm{~mL})$. The organic phase was dried with $\mathrm{MgSO}_{4}$, the solvent evaporated under reduced pressure and the residue chromatographed using hexane/EtOAc (8:2). Colourless oil. $73 \%$ yield. $[\alpha]_{\mathrm{D}}{ }^{21}=+86.5^{\circ}\left(\mathrm{c} 0.81, \mathrm{CDCl}_{3}\right) .{ }^{1} \mathrm{H}$ NMR $\left(300 \mathrm{MHz}, \mathrm{CDCl}_{3}\right), \delta$ (ppm): 7.97-8.01 (m, 2H, H arom); 7.42-7.66 (m, 3H, H arom); 4.41 (t, 2H, J=7.9 Hz, H7); 3.25 $(\mathrm{m}, 1 \mathrm{H}, \mathrm{H} 2) ; 2.37$ (m, 2H, H6); 2.22(q, $1 \mathrm{H}, J=6.4 \mathrm{~Hz}, \mathrm{H} 4) ; 1.41\left(\mathrm{~d}, 3 \mathrm{H}, J=6.4 \mathrm{~Hz}, \mathrm{CH}_{3}\right) .{ }^{13} \mathrm{C}$ NMR (75 MHz, $\left.\mathrm{CDCl}_{3}\right) \delta(\mathrm{ppm}): 196.1,175.7,137.4,133.5,128.7,128.2,66.6,36.6,36.1,30.7$, 28.1, 11.4. IR (NaCl) 2962, 2928, 2873, 1762, 1641, 1597, 1575, 1449.2, 1374, 1239, $1135 \mathrm{~cm}^{-1}$. MS (Electrospray): $253.1\left(\mathrm{M}^{+}+\mathrm{Na}^{+}\right), 231.1\left(\mathrm{M}^{+}+1\right)$. Anal. calcd for $\mathrm{C}_{14} \mathrm{H}_{14} \mathrm{O}_{3}: \mathrm{C}, 73.03 ; \mathrm{H}$, 6.13. Found: C, 73.12; H, 6.09 .

\section{Acknowledgments}

We thank Lilly S.A. Spain for financial support of this research. S. M. is grateful to Lilly S. A. for a fellowship.

\section{References}

1. Donaldson, W. A. Tetrahedron 2001, 57, 8589.

2. (a) Simmons, H. E.; Smith, R. D. J. Am. Chem. Soc. 1958, 80, 5323. (b) Simmons, H. E.; Smith, R. D. J. Am. Chem. Soc. 1959, 81, 4256. (c) Simmons, H. E.; Cairns, T. L.; Vladuchick, S. A.; Hoiness, C. M. Org. React. 1973, 20, 1.

3. Paulissen, R.; Hubert, A. J.; Teyssie, Ph. Tetrahedron Lett. 1972, 1465. (b) Mende, U.; Radüchel, B.; Skuballa, W.; Vorbrüggen, H. Tetrahedron Lett. 1975, 629. (c) Suda, M. Synthesis 1981, 714.

4. Doyle, M. P.; McKervey, M. A.; Ye, T. Modern Catalytic Methods for Organic Synthesis via Diazo Compounds; Wiley; New York, 1998, pp 163-288.

5. Corey, E.; Chaykovsky, M. J. Am. Chem. Soc. 1965, 1353.

6. (a) Helquist, P. In Comprehensive Organic Synthesis Pergamon Press: New York, 1991, vol. 4, pp 968. (b) Salaün, J. Chem. Rev. 1989, 89, 1247. 
7. Najera, C.; Chinchilla, R.; García-Granda, S. Tetrahedron Lett. 1993, 34, 5799 and relevant references cited therein.

8. Lebel, H.; Marcoux, J-F.; Molinaro, C.; Charette, A. B. Chem. Rev. 2003, 103, 977.

9. Takahashi, T.; Yamashita, Y.; Doi, T.; Tsuji, J. J. Org. Chem. 1989, 54, 4273.

10. (a) Ma, D.; Ma, Z. Tetrahedron Lett.1997, 43, 7599. (b) Ma, D.; Cao, Y.; Yang, Y.; Cheng, D. Org. Lett. 1999, 1, 285. (c) Ma, D.; Jiang, Y. Tetrahedron: Asymmetry 2000, 11, 3727.

11. (a) Hanessian, S.; Androetti, D.; Gomtsyan, A. J. Am. Chem. Soc. 1995, 117, 10393. (b) Hanessian, S.; Gomtsyan, A.; Payne, A.; Herve, Y.; Beaudoin, S. J. Org. Chem. 1993, 58, 5032.

12. Mamai, A.; Madalengoitia, J. S. Tetrahedron Lett. 2000, 41, 9009.

13. Barluenga, J.; Suárez-Sobrino, A. L.; Tomás M.; García-Granda, S.; Santiago-García, R. J. Am. Chem. Soc. 2001, 123, 10494 and references cited therein.

14. Collado, I.; Domínguez, C.; Ezquerra, J.; Pedregal, C.; Monn, J. A. Tetrahedron Lett. 1997, 38, 2133.

15. (a) Domínguez, C.; Ezquerra, J.; Prieto, L.; Espada, M.; Pedregal, C.Tetrahedron: Asymmetry 1997, 8, 511. (b) Dominguez, C.; Ezquerra, J.; Baker, S. R.; Borrelly, S.; Prieto, L.; Espada, M.; Pedregal, C. Tetrahedron Lett. 1998, 39, 9305.

16. Ezquerra, J.; Pedregal, C.; Rubio, A.; Vaquero, J. J.; Matia, M. P.; Martín, J.; García Navio, J. L. J. Org. Chem. 1994, 59, 4327.

17. Ezquerra, J.; Rubio, A.; Martín, J.; García Navío, J. L. Tetrahedron: Asymmetry 1997, 8, 669.

18. Ezquerra, J.; Prieto, L.; Avendaño, C.; Martos, J. L.; de la Cuesta, E. Tetrahedron Lett.1995, 36, 2559.

19. Payne, G. B. J. Org. Chem. 1967, 32, 3351.

20. Trost, B. M.; Arndt, H. C. J. Org. Chem. 1973, 38, 3140.

21. NP-HPLC, semipreparative HPLC, chiral NP-HPLC and NMR experiments were used for separation and structure determination of 3a-d. (a) De la Puente, M.L.; White, C.T.; RiveraSagredo, A.; Reilly, J.; Burton, K.; Harvey G. J. Chromatogr. A, 2003, 101, 983. (b) De la Puente, M.L. J. Chromatogr. A, 2004, 55, 1055

22. X-Ray data is included in the supporting information.

23. Mantecón, S.; Vaquero, J. J.; Alvarez-Builla, J.; de la Puente, M. L.; Espinosa, J. F.; Ezquerra, J. Org. Lett. 2003, 5, 3791. 